International Journal of Agriculture, Environment and Bioresearch

Vol. 06, No. 05; 2021

ISSN: $2456-8643$

\title{
EFFECT OF TEMPERATURE AND DRIP IRRIGATION ON BEAN PRODUCTIVITY IN THE YAQUI VALLEY DURING THE SPRING 2020
}

\author{
FÉLIX-VALENCIA Pedro,ORTIZ-ENRÍQUEZ José Eliseo, FUENTES-DÁVILA Guillermo, MUÑOZ- \\ VALENZUELA Sergio, PADILLA-VALENZUELA Isidoro, and TORRES-CRUZ María Monserrat \\ INIFAP, CAMPO EXPERIMENTAL VALLE DEL YAQUI ,Apdo. Postal 155, km 12 Norman E. Borlaug, entre 800 \\ y 900, Valle del Yaqui, Cd. Obregón, Sonora, México CP 85000 \\ https://doi.org/10.35410/IJAEB.2021.5671
}

\begin{abstract}
The fructification period of pinto bean cultivar BillZ was evaluated in three commercial fields, in relation to the effect of drip irrigation with the temperature regime within the crop, in the Yaqui Valley, Sonora, Mexico, during the spring season 2020. Five warm periods with a maximum temperature range from 36 to $40^{\circ} \mathrm{C}$ were recorded from the flowering stage to completely filled grain. Maturity to harvest was reduced between 6 to 10 days with respect to the normal of 100 days. All fields recorded between 10.4 and $27 \%$ of pods without grain, and those with grains showed variable weight. The bean field with the highest grain yield had an average thermic level of 32 to $33^{\circ} \mathrm{C}$; as the temperature rose above this level with continuous 8 hour periods (10:00 am-18:00 pm), the highest detachment of flowers and pods shorter than $2 \mathrm{~cm}$ were recorded. With respect to the theoretical water use by evapotranspiration, the sheets of water applied by the farmer were sufficient with the exception of the field with a theoretical irrigation deficit between 27 and 33\%. The interaction of temperature with irrigation water sheets was highly significant for all variables; the highest grain yield was attributable to the well programed irrigation and to a minor differential average temperature of $1.9^{\circ} \mathrm{C}$ during the flowering period to harvest.
\end{abstract}

Keywords: Common bean, Phaseolus vulgaris, temperature, drip irrigation.

\section{INTRODUCTION}

Common bean (Phaseolus vulgaris L.) is an important crop in many countries since it is a primary component in human consumption. In the first decade of the present century, Brazil was the leader in productivity with $16 \%$, followed by India (15.9\%), Myanmar (10.5\%), China (8.9\%), and Mexico (5.8\%) (Lépiz et al., 2015). Although Mexico has beenone of the leaders in bean production generating 5.8\% of the world production, during 2003-2016 an accumulated reduction was observed in area sown with bean (20.01\%) as well as in productivity (23.05\%) (SAGARPA, 2017).Bean is a key crop in the mexican diet with $9.9 \mathrm{~kg}$ per capita consumption; the national production covers almost the total domestic requirement. During the year 2016, 1.08 million $\mathrm{t}$ produced covered $89.24 \%$ of the domestic consumption, the rest was supplied by importations from the United States (84.07\%), Canada (13.47\%), and China (2.05\%). The production bean systems in Mexico are based on: 1) sowing season (spring, spring-summer, and fall-winter), 2) humidity conditions (rainfed and irrigated), and 3) socioeconomic level (subsistence farming and business agriculture) (Acosta et al., 2000). Aproximately, 76.07\% of the crop is established under rainfed conditions. The main bean types sown and consumed are: national and american pinto, regional azufrado and peruvian azufrado, flor de mayo, flor de 
Vol. 06, No. 05; 2021

ISSN: $2456-8643$

junio, negro and bayo. Consumption habits vary with the region, so in the northwest the preference is the azufrado types, and pintos and bayos in the north and northeast. Although in central Mexico all types of beans are consumed, there is a marked tendendy for flor de mayo and in the south black beans are preferred (Castellanos et al., 1997). During the spring-summer season 2020, under irrigation and rainfed conditions, common bean production in Mexico was $729,337.97 \mathrm{t}$ from an area of 1,314,933.40 ha in 29 states with an average yield of $0.55 \mathrm{t} / \mathrm{ha}$; the state of Zacatecas had the largest area sown with bean (639,850.50 ha) (SIAP, 2021). In the state of Sonora, under rainfed conditions there were 94 ha harvested with a production of $64.25 \mathrm{t}$ with an average yield of $0.68 \mathrm{t} / \mathrm{ha}$, while under irrigation there were $2,431.5$ ha harvested with a production of 5,494.18 t with an average yield of $2.26 \mathrm{t} / \mathrm{ha}$ (SIAP, 2021).In the Yaqui Valley which is part of the southern region of the state, farmers use several ways for irrigation: flooding, furrow, drip, center pivot, frontal move, and spray irrigation (SAGARHPA, 2011). The most common is furrow irrigation. In the case of beans which has increased in area in the last few years (INIFAP, 2020), farmers use primarily furrow irrigation and secondly drip irrigation.Some of the main constrains for bean production in Sonora are Bean common mosaic virus, Bean southern mosaic virus, Bean chlorotic mosaic virus, Bean golden yellow mosaic virus, Pumpkin leaf curly (Padilla et al., 2000), and rust caused by the fungusUromyces appendiculatus var. appendiculatus (Valenzuela and Armenta, 1990; Ramírez, 1991).Analysis of the temperature during the last 10 years in southern Sonora, Mexico, indicates that the spring season (FebruaryMay) of beanhas maintained a $0.2^{\circ} \mathrm{C}$ increase tendency per season, mainly during the months of April and May (REMAS, 2021). The events of extreme minimum temperature have a tendency to increase and the relative humidity has been unstable. Generally, the southern region of the state of Sonora, is characterized by extreme minimum temperatures of $-1.8^{\circ} \mathrm{C}$ mainly in January, and extreme maximum temperatures of 32.5 to $44.2^{\circ} \mathrm{C}$ during June, July, and August; although in certain years like 2020 , temperatures above $32^{\circ} \mathrm{C}$ during the day migh occur in May and September (REMAS, 2021). The wide environmental adaptability reported in some edible bean types, indicates that some cultivars may stand extreme temperatures between 5 and $40^{\circ} \mathrm{C}$ (White and Singh, 1991).Sowing bean during the spring is a feasible option for farmers who cultivate a fall-winter crop and take advantage of the residual fertilization, the water assignment, and the minimum till, with a short season crop like bean; therefore, it is important to determine the risk level that bean might have, if sowing is carried out outside the established technical dates recommended for the region (Padilla-Valenzuelaet al., 2009). The objective of this work was to evaluate bean fructification-production period during the spring 2020, under the thermic impact caused by sowing outside the recommended dates and under drip irrigation.

\section{MATERIALS AND METHODS}

The productive phase of bean cultivar Pinto Bill $\mathrm{Z}$ was analyzed in three commercial fields located in Blocks 1502 (100 ha), 2110 (100 ha), and 2228 (290 ha) (Fig. 1), in the Yaqui Valley, Sonora, Mexico, during the spring 2020, under drip irrigation and the temperatures that prevailed during the season. The irrigation tape was Stream line 8000 with a capacity of 0.89 liter of water per hour by each dropper, which were separated by $30 \mathrm{~cm}$. Digital sensors Omega (OM-ELWIN-USB data Logger software v7.2.1) were placed in each field to record temperature and relative humidity within the crop; as a reference, climatic data but primarily Eto (evapotranspiration), were also obtained from weather stations of the automated weather station 
network in the state of Sonora (REMAS), which were located in: 1) Block 1703, $7 \mathrm{~km}$ south of the sensor in Block 1502, 2) Block 2010, $4 \mathrm{~km}$ north of sensor in Block 2110, and 3) Block $2328,4 \mathrm{~km}$ south of sensor in Block 2228.

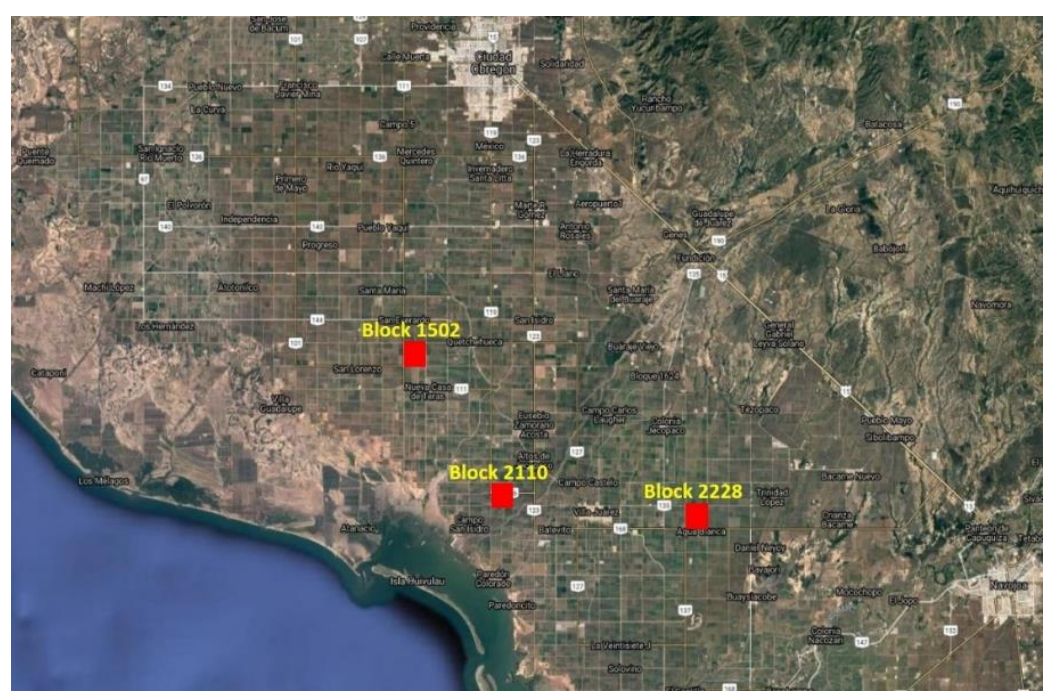

Figure 1.

Blocks where the productive phase of bean cultivar Pinto Bill $\mathrm{Z}$ was evaluated in the Yaqui Valley, Sonora, Mexico, during the spring 2020.

The Eto of a crop is an indicator of water demand by the crop (Penman-Monteith cited by Allen et al., 1998), and indirectly estimates the water sheet needed. The climatic date based was generated in hourly format from February to June, 2020.Due to the shortage of water, fields in Blocks 1502 and 2228 were divided into two sections, one with higher irrigation sheet $(\mathrm{H})$ and the other with a low irrigation sheet.Sowing dates for field B-1502Hwas March 26, for B-1502 March 31, B-2110 March 25, B-2228H February 20, and for B-2228 March 09. Irrigation sheets were calculated based on the number of hours, use of water by the irrigation hose, and irrigation frequency.Three $1 \mathrm{~m}^{2}$ plant samples were collected from each field to quantify pod production, pods with grain, a thousand grain weight, and grain yield.The sources of variation were the irrigation sheets and temperature.The analysis of variance was performed with the programInfoStatof Balzarini (2008).

\section{RESULTS AND DISCUSSION}

Periods of temperature with a threshold greater than $30^{\circ} \mathrm{C}$ were recorded between March 10 and 11, 24 and 25, April 7 and 8, 14 and 18, and from April 20 onward the temperature increased up to the time of harvest and had oscillations greater than $40^{\circ} \mathrm{C}$; this last heat wave was detected in 90\% of the weather stations.Temperature records within fields (Fig. 2) showed that plants standed average thermic levels of $32.5^{\circ} \mathrm{C}$, with periods of 8 continuous hours (10:00am-18:00 $\mathrm{pm}$ ) with constant irrigation, according to the best yield recorded in the field located in Block 2110. 


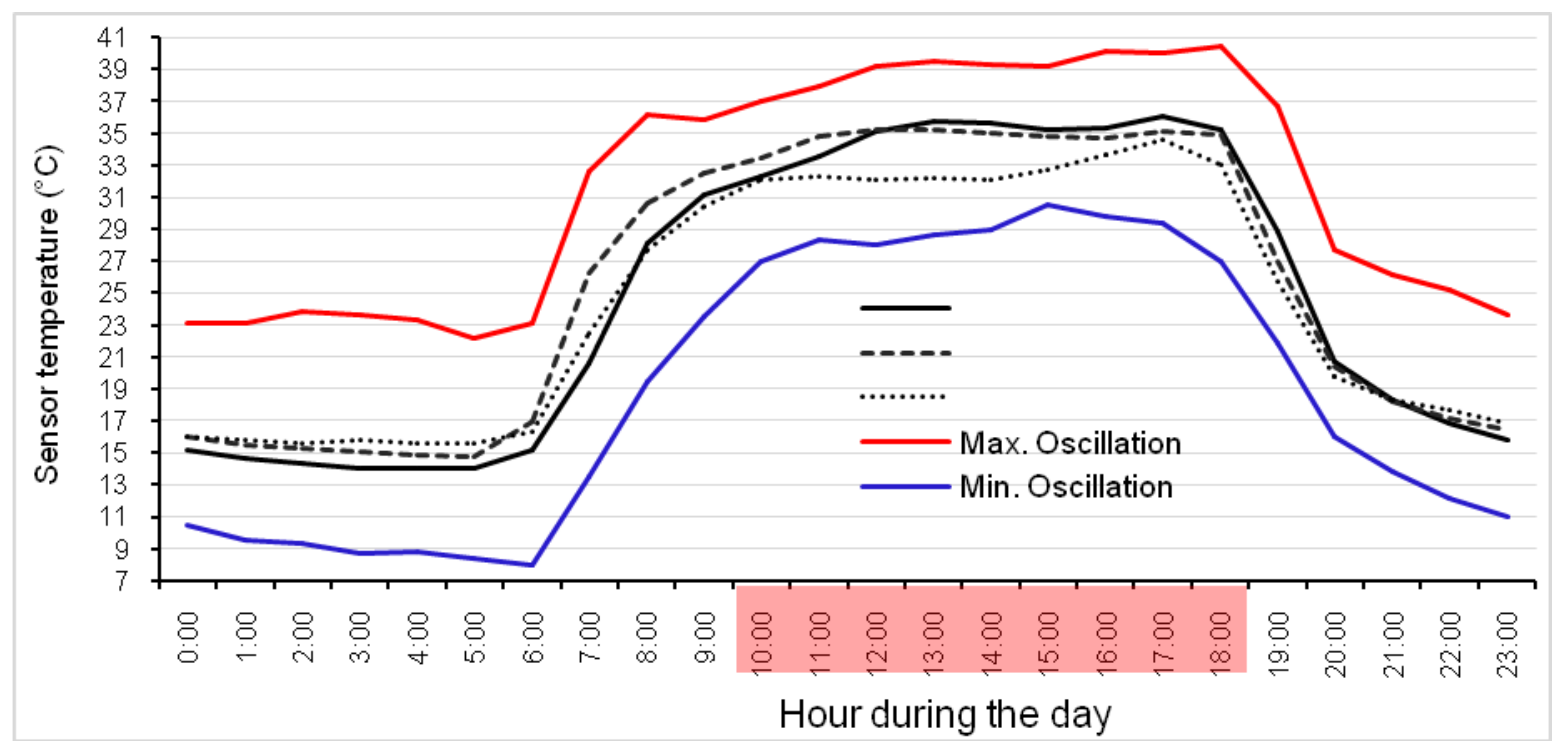

Figure2. Temperature records obtained from a digital sensor within the crop. Average of the flowering period to grain maturity, in the Yaqui Valley, Sonora, Mexico, during the spring 2020.

When the temperature rose above this level, there was greater flower and pod (less than $2 \mathrm{~cm}$ in length) fall off, and its effect increased in the second and third portion of the plant. Monterroso and Wien (1990) reported that a 10 hour period at $35^{\circ} \mathrm{C}$ for two days during the flowering stage, caused $82 \%$ abscission of pods (shorter than $2 \mathrm{~cm}$ ) and pollen dehydration.

Similar to the weather stations, sensors within the crop recorded in certain days during the period of study, temperatures greater than $36^{\circ} \mathrm{C}$, reaching $40.5^{\circ} \mathrm{C}$ (Fig. 2). The highest average temperature was recorded in fields located in Blocks 2228 and 1502.The thermic differences between fields could be related to the frequency of irrigation and closeness to the ocean. The maturity to harvest period was related to the irrigation sheet and temperature, and so the field in Block 2228 accelerated the maturity, followed by 1502 .Field observations indicated a reduction in pod size (Fig. 3A), and grain size and weight (Fig. 3B), as a compensatory effect by temperature excess and lack of water.Previous studies carried out by Turner (1990), Efetha et al. (2011), andBárzaga (2010), indicate that water stress will cause a reduction in the size and number of grains per pod, consequently a reduction in grain yield per area (Efetha et al., 2011;Elmetwali and Ibrahim, 2016;Rai et al., 2020).Table 1 describes the theoretical amount of water used by the crop that was recorded by the weather station closest to the field. For bean fields B-2110, B-1502-H, and B-1502, sown on March 25, 26, and 31, respectively, it was 49, 41 , and $39 \mathrm{~cm}$; and the irrigation sheets applied were 48,42 , and $38 \mathrm{~cm}$ which indicates sufficiency of irrigation with respect to the period from sowing to harvest. For bean fields in B2228-H and B-2228 sown on February 20 and March 9, respectively, the weather station recorded a theoretical water use of 49 and $43 \mathrm{~cm}$; irrigation sheets of 36 and $29 \mathrm{~cm}$ were applied, respectively, which renders a theoretical deficit between 27 and 33\%. Counting total pods and those without grain, showed that in the three fields there were pods without grain (Fig. 3C), so that damage to pods accounted for between 10.4 a 27\%, (Table 1). Pods that were threshed had one, two, three, and exceptionally four grains per pod. Grain development was variable in size 
and weight in the three fields, as well as the number of pods with grain. The significant differences in higher grain yield were influenced by greater irrigation sheet with a lower temperature (Tables 2 and 3).

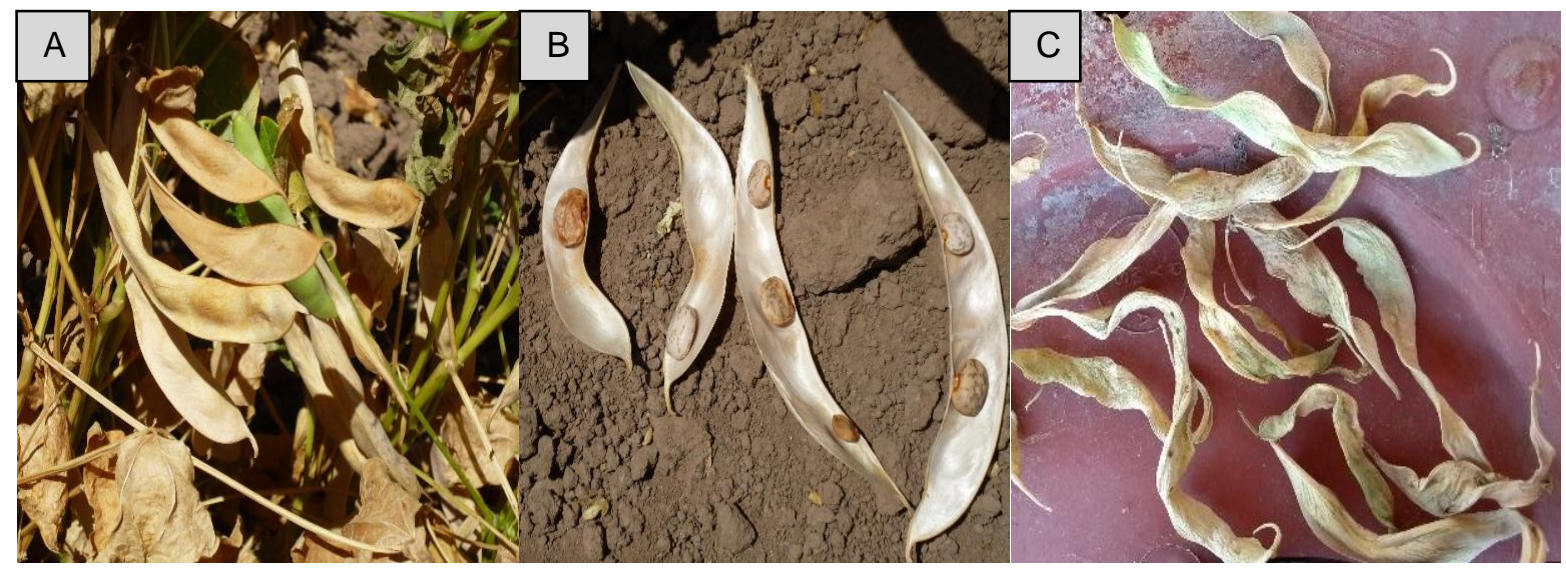

Figure 3. Pods from commercial bean cultivar Pinto Bill Z sown in the Yaqui Valley, Sonora, Mexico, during the spring 2020.

Table 1. Water use calculated based on the evapotranspiration, days to harvest, and percentage of pods without grain, in three commercial fields in the Yaqui Valley, Sonora, Mexico, during the spring 2020.

\begin{tabular}{|l|l|l|l|l|}
\hline Fields & Sowing dates & $\begin{array}{l}\text { Evapotranspiration } \\
(\mathrm{cm})^{*}\end{array}$ & Days to harvest & $\begin{array}{l}\text { Pods without } \\
\text { grain(\%) }\end{array}$ \\
\hline B-2110 & Mar-25 & 49 & 86 & 15.2 \\
\hline B-1502-H & Mar-26 & 41 & 84 & 10.4 \\
\hline B-1502 & Mar-31 & 39 & 80 & 15.5 \\
\hline B-2228-H & Feb-20 & 49 & 89 & 13.3 \\
\hline B-2228 & Mar-09 & 43 & 80 & 27.0 \\
\hline
\end{tabular}

*Calculatedbasedon the sowing date to harvest, using the weather station closest to the field.

Studies carried out by Padilla-Valenzuela (1992) with Pinto Bill Z cultivar, indicated that the normal bean spring season lasts 100 days from sowing to harvest, and that if the season is shortened by 8 days, grain yield will be reduced by $16 \%$.In this evaluation, the season was shortened to harvest by 6 to 10 days; this season reduction is closely related to an increase in temperature and to the frequency irrigation differential, according to field observations, which derived in highly significant difference in grain yield (Tables 2, 3, and 4).A nonquantified statistical effect was the irrigation frequency, which was prolongued by insufficiency in water supply to fields located in Block 2228 and 1502. 
Table 2. Analysis of varianceof the response variables of bean cultivar Pinto Bill Zwith irrigation sheets and average temperature of the period, in three commercial fields in the Yaqui Valley, Sonora, Mexico, during the spring 2020.

\begin{tabular}{|l|lll|lcl|}
\hline \multirow{2}{*}{ Response variable } & \multicolumn{3}{|l|}{ Temperature Vs. } & \multicolumn{3}{l|}{ Irrigation sheet Vs. } \\
\cline { 2 - 7 } & $\mathrm{R}^{2}$ & $\mathrm{CV} \%$ & $\mathrm{p}>0.01$ & $\mathrm{R}^{2}$ & $\mathrm{CV} \%$ & $\mathrm{p}>0.01$ \\
\hline Total pods & 0.64 & 5.3 & $0.0023^{* *}$ & 0.79 & 17.0 & $0.0019^{* *}$ \\
Pods with grain & 0.56 & 5.7 & $0.0076^{* *}$ & 0.73 & 22.4 & $0.0068^{* *}$ \\
Weight of 1000 grains (g) & 0.72 & 1.5 & $0.0004^{* *}$ & 0.78 & 7.4 & $0.0023^{* *}$ \\
Grain yield (kg/ha) & 0.69 & 49.7 & $0.0009^{* *}$ & 0.72 & 31.4 & $0.0081^{* *}$ \\
\hline
\end{tabular}

Table 3. Response variables of bean cultivar Pinto Bill $Z$ with different irrigation sheets, in three commercial fields in the Yaqui Valley, Sonora, Mexico, during the spring 2020.

\begin{tabular}{|c|c|c|c|c|c|c|}
\hline Block-field & $\begin{array}{l}\text { Irrigation } \\
\text { sheet }(\mathrm{cm})\end{array}$ & $\begin{array}{l}\text { Total } \\
\text { pods }\end{array}$ & $\begin{array}{l}\text { Pods } \\
\text { grain }\end{array}$ & with & $\begin{array}{lr}\text { Weight } & \text { of } \\
1000 & \text { grains } \\
(\mathrm{g}) & \\
\end{array}$ & $\begin{array}{l}\text { Grain } \\
(\mathrm{kg} / \mathrm{ha})\end{array}$ \\
\hline B-2110 & 48 & $406 \mathrm{a}$ & $344 \mathrm{a}$ & & $270 \mathrm{a}$ & $3430 \mathrm{a}$ \\
\hline B-1502-H & 42 & $328 \mathrm{ab}$ & 294 a & & $239 a b$ & $2096 \mathrm{~b}$ \\
\hline B-1502 & 38 & $366 a b$ & $309 a$ & & $236 \mathrm{~b}$ & $1824 \mathrm{~b}$ \\
\hline B-2228-H & 36 & $275 \mathrm{~b}$ & $239 a$ & & $191 \mathrm{c}$ & $1489 \mathrm{~b}$ \\
\hline B-2228 & 29 & $165 \mathrm{c}$ & $120 \mathrm{~b}$ & & $214 \mathrm{bcc}$ & $1033 \mathrm{~b}$ \\
\hline
\end{tabular}

Numbers with the same letter in a column are not statistically different (Tukey's test, 0.05).

Table 4. Response variables of bean cultivar Pinto Bill $Z$ under different average temperature regimes, in three commercial fields in the Yaqui Valley, Sonora, Mexico, during the spring 2020.

\begin{tabular}{|c|c|c|c|c|c|}
\hline Block-field & $\begin{array}{l}\text { Average } \\
\text { temperature } \\
\left({ }^{\circ} \mathrm{C}\right)\end{array}$ & $\begin{array}{l}\text { Total } \\
\text { pods }\end{array}$ & $\begin{array}{l}\text { Pods } \\
\text { grain }\end{array}$ & $\begin{array}{l}\text { Weight } \text { of } \\
1000 \text { grains } \\
(\mathrm{g})\end{array}$ & $\begin{array}{l}\text { Grain } \\
\text { yield(kg/ha) }\end{array}$ \\
\hline B-2110 & 32.5 & $406 \mathrm{a}$ & $344 \mathrm{a}$ & $270 \mathrm{a}$ & $3430 \mathrm{a}$ \\
\hline B-1502* & 34.2 & $347 \mathrm{a}$ & $301 \mathrm{a}$ & $237 \mathrm{~b}$ & $1960 \mathrm{~b}$ \\
\hline B-2228* & 34.6 & $220 \mathrm{~b}$ & $180 \mathrm{~b}$ & $203 \mathrm{c}$ & $1261 \mathrm{~b}$ \\
\hline
\end{tabular}

*Average of the two sections of the field.

Numbers with the same letter in a column are not statistically different (Tukey's test, 0.05).

\section{CONCLUSIONS}

Temperature oscillation greater than $32.5^{\circ} \mathrm{C}$ caused a reduction in pod number with grains in all the fields.The interaction temperature by irrigation sheet significantly affected the number and grain weight. The irrigation programmed and sufficient, congruent with the evapotranspiration, provided a significant beneficial grain yield to the field located in Block 2110 during this warm 
Vol. 06, No. 05; 2021

ISSN: $2456-8643$

season.Spring sowing in southern Sonora has a high risk in warm seasons, but it is an economic feasible option, as long as the irrigation is well programmed and sufficient.

\section{REFERENCES}

Acosta GJA, Rosales SR, Navarrete MR y López SE. 2000. Desarrollo de variedades mejoradas de frijol para condiciones de riego y temporal en México. Agricultura Técnica en México 26(1):79-98.

Allen RG, Pereira LS, Raes D, and Smith M.1998. Crop evapotranspiration-Guide lines for computing crop water requirements. FAO Irrigation and Drainage paper 56. Rome, Italy.http://www.fao.org/3/x0490e/x0490e00.htm. Accessed on November 25, 2020.

Castellanos J, Guzmán MH, Jiménez A, Majía C, Muñoz RJJ, Acosta GJ, Hoyos G, López SE, González ED, Salinas PR, González AJ, Muñoz VJ, Fernández HP y Cáceres B. 1997. Hábitos preferenciales de los consumidores de frijol común (Phaseolus vulgaris L.) en México. Archivos Latinoamericanos de Nutrición 47(2):163-167.

Barzaga RI. 2010. Efecto de la sequía en el crecimiento y desarrollo del cultivo de frijol común (Phaseolus vulgaris L.) en condiciones de campo. Trabajo de Diploma en opción al título de Ingeniero Agropecuario. Universidad de Granma. Bayazo, Cuba. 45 p.

Efetha A, Harms TE, and Bandara M. 2011. Irrigation management practices for maximizing seed yield and water use efficiency of Othello dry bean (Phaseolus vulgaris L.) in southern Alberta, Canada. Irrigation Science 29(2):103-113. DOI:10.1007/s00271-010-0220-x.

Elmetwali A, and Ibrahim MM. 2016. Improving water productivity of beans through double ridge furrow irrigation method. Misr Journal of Agricultural Engineering 33(4):1387-1398. DOI:10.21608/mjae.2016.97610.

InfoStat. 2008. Manual del Usuario, versión 2008. Facultad de Ciencias Agropecuarias, Universidad Nacional de Córdoba. Córdoba, Argentina. 334 p.

Instituto Nacional de Investigaciones Forestales, Agrícolas y Pecuarias (INIFAP). 2021. Avanza en Sonora el proyecto: Refrescamiento de semilla de frijol para México https://www.gob.mx/inifap/articulos/avanza-en-sonora-el-proyecto-refrescamiento-de-semillade-frijol-para-mexico?idiom=es. Accessed on July 15, 2021.

Lépiz IR, Sánchez PS, López AE, López AJJ, Chavarín EIE, y Meza VKE. 2015. El cultivo de frijol en Jalisco. Tecnología para altos rendimientos. Universidad de Guadalajara. Las agujas, Municipio de Zapopan, Jalisco, México. 54 p.

Monterroso VA, and Wien HC.1990. Flower and pod abscission due to heat stress in beans. Journal of the American Society of Horticultural Science 115(4):631-634.

Padilla-ValenzuelaI. 1992. Época de corte en frijol (Phaseolus vulgaris L.): efecto en el rendimiento y calidad del grano. In: Memorias del XIV Congreso Nacional de Citogenética. Tuxtla Gutiérrez, Chiapas, México.p. 417.

Padilla VI, Armenta CI., Ramírez AJA y Madrid CM. 2000. Tecnología para producir frijol en el Sur de Sonora. Folleto para productores No. 17. SAGARPA-INIFAP-Campo Experimental Valle del Mayo. Navojoa, Sonora, México. 24 p.

Padilla-Valenzuela I, Castillo-Torres N, Ramírez-Arredondo JA, Armenta-Cárdenas I, CabreraCarbajal F, Madrid-Cruz M y Ortiz-Enríquez JE. 2009. Manual para la producción de frijol en el Sur de Sonora. Folleto Técnico No. 69. SAGARPA-INIFAP-Campo Experimental Valle del Yaqui. Ciudad Obregón, Sonora, México. 122 p. 
Rai A, Sharma V, and Heitholt J. 2020. Dry bean (Phaseolus vulgaris L.) growth and yield response to variable irrigation in the arid to semi-arid climate. Sustainability 12(9):3851. DOI:10.3390/su12093851

Ramírez AJA. 1991. Control químico de Uromyces phaseoli var. typica y Erysiphe polygoni en frijol en el Valle del Mayo, Sonora. XVIII Congreso Nacional de Fitopatología. 24 al 26 de julio de 1991. Puebla, Puebla, México.

REMAS (Red de Estaciones Metereológicas Automáticas de Sonora). 2021. Descargar datos. http://www.siafeson.com/remas/. Accessed on July 15, 2021.

SAGARHPA (Secretaría de Agricultura, Ganadería, Recursos Hidráulicos, Pesca y Acuacultura, Sonora). 2011. Estudio sobre la Situación de la Tecnificación del Riego en el Estado de Sonora. Hermosillo, Sonora, México. 111 p.

SAGARPA (Secretaría de Agricultura, Ganadería, Desarrollo Rural, Pesca y Alimentación). 2017. Planeación agrícola nacional. Frijol mexicano. https://www.gob.mx/ cms/uploads/ attachment/file/256428/B sico-Frijol.pdf. Accessed on September 15, 2021.

SIAP (Servicio de Información Agroalimentaria y Pesquera). 2021. Anuario estadístico de la producción agrícola. https://nube.siap.gob.mx/cierreagricola/. Accessed on May 20, 2021.

TurnerNC. 1990.The benefits of water deficit. In:Procceding of the International Congress of Plant Physiology2:806-815. New Delhi, India.

Valenzuela LJ y Armenta CI. 1990. Guía para cultivar frijol en el sur de Sonora. Folleto para productores No 1. Campo Experimental Valle del Mayo. SAGARPA-INIFAP-CIANO. Cd. Obregón, Sonora, México. 16 p.

White JW, and Singh SP. 1991. Breeding for adaptation to drought. In: Art Van Schoonhoven and O. Voysest (eds.) Common bean: Research for Crop Improvement. CAB International (Centre for Agricultural Bioscience International) and CIAT (Centro Internacional de Agricultura Tropical). Cali, Colombia. pp. 501-560. 